\title{
Nucleotide diversity and population differentiation of the Melanocortin I Receptor gene, MCIR
}

\author{
Sharon A Savage*1, Meg R Gerstenblith ${ }^{2}$, Alisa M Goldstein'2, Lisa Mirabello1, \\ Maria Concetta Fargnoli ${ }^{3}$, Ketty Peris ${ }^{3}$ and Maria Teresa Landi ${ }^{2}$
}

Address: ${ }^{1}$ Clinical Genetics Branch, Division of Cancer Epidemiology and Genetics, National Cancer Institute, National Institutes of Health, Department of Health and Human Services, USA, ${ }^{2}$ Genetic Epidemiology Branch, Division of Cancer Epidemiology and Genetics, National Cancer Institute, National Institutes of Health, Department of Health and Human Services, USA and ${ }^{3}$ Department of Dermatology, University of L'Aquila, Via Vetoio - Coppito 2, 67100 L'Aquila, Italy

Email: Sharon A Savage* - savagesh@mail.nih.gov; Meg R Gerstenblith - mgerstenblith@gmail.com; Alisa M Goldstein - goldstea@mail.nih.gov; Lisa Mirabello - mirabellol@mail.nih.gov; Maria Concetta Fargnoli - fargnoli@univaq.it; Ketty Peris - peris@univaq.it;

Maria Teresa Landi - andim@mail.nih.gov

* Corresponding author

Published: 10 April 2008

BMC Genetics 2008, 9:31 doi:10.1|86/|47|-2|56-9-3|
Received: I November 2007

Accepted: 10 April 2008

This article is available from: http://www.biomedcentral.com/I47I-2/56/9/3।

(C) 2008 Savage et al; licensee BioMed Central Ltd.

This is an Open Access article distributed under the terms of the Creative Commons Attribution License (http://creativecommons.org/licenses/by/2.0), which permits unrestricted use, distribution, and reproduction in any medium, provided the original work is properly cited.

\begin{abstract}
Background: The melanocortin I receptor gene $(M C I R)$ is responsible for normal pigment variation in humans and is highly polymorphic with numerous population-specific alleles. Some $M C I R$ variants have been associated with skin cancer risk.

Results: Allele frequency data were compiled on 55 single nucleotide polymorphisms from seven geographically distinct human populations ( $\mathrm{n}=2306$ individuals). $M C I R$ nucleotide diversity, $\pi$, was much higher $\left(10.1 \times 10^{-4}\right)$ than in other genes for all subjects. A large degree of population differentiation, determined by $F_{S T}$, was also present, particularly between Asia and all other populations, due to the p.RI63Q (c.488 G>A) polymorphism. The least amount of differentiation was between the United States, Northern Europe, and Southern Europe. Tajima's D statistic suggested the presence of positive selection in individuals from Europe.
\end{abstract}

Conclusion: This study further quantifies the degree of population-specific genetic variation and suggests that positive selection may be present in European populations in MCIR.

\section{Background}

Differences in human skin pigmentation have been attributed to genetic variation in several different genes [1-3]. Among these, the melanocortin 1 receptor gene $(M C 1 R$, MIM\#155555), a member of the G protein-coupled receptors superfamily, is the major contributor to normal pigment variation in humans. It is a small, highly polymorphic gene consisting of one exon with 951 coding nucleotides on chromosome 16q24.3.
Numerous studies have demonstrated associations between specific $M C 1 R$ variants and red hair, light skin, poor tanning ability and heavy freckling [4-9]. A recent genome-wide association scan confirmed the role of $M C 1 R$ SNPs in hair, eye, and skin pigmentation[3]. The functional role of many of these variants has been described [10-13]. Several MC1R variants are also associated with increased risk of malignant melanoma in a variety of populations [14-22] The effect of MC1R polymorphisms in melanoma risk appears to extend 
beyond its effect on pigmentation in most of these investigations, and to be linked to melanomas harboring mutations in the BRAF oncogene[23].

Several hypotheses have been generated in an effort to understand the evolutionary history of skin pigmentation in humans. It has been suggested that as humans migrated out of Africa to climates with more limited exposure to sunlight, relaxation of functional constraints in pigmentation genes, including $M C 1 R$, or selection for functionally relevant variants that led to lighter skin pigmentation occurred[24]. This could result in an improved ability to synthesize vitamin D in the presence of limited sunlight exposures [25-27]. It has also been suggested that darker skin is favored in regions closer to the equator for protection against ultraviolet radiation[24]. In addition, differences in skin pigmentation could protect against pathogens and cold injury, and may have also been important in sexual selection[28].

Genetic variation of $M C 1 R$, in the form of single nucleotide polymorphisms (SNPs), is significantly different across populations from different geographic regions $[29,30]$. In most regions of the genome, there is a higher degree of genetic variation in individuals of African descent than in other populations, most likely due to evolutionary history [31,32]. MC1R is an exception to this observation. It has been shown to be more polymorphic in individuals of European descent than in those from Africa $[29,30]$. A comprehensive study of SNP allele frequencies in MC1R from populations around the world, further quantified the large differences in the distribution of variants across populations, with a prominent difference between light and dark-pigmented individuals [29]. The goal of the current study was to expand on that study of $M C 1 R$ genetic variation by characterizing nucleotide diversity, population specific differentiation $\left(\mathrm{F}_{\mathrm{ST}}\right)$, and to study measures of selection.

\section{Results}

\section{Nucleotide Diversity}

Allele frequency (AF) data was compiled from a total of 2306 individuals who were grouped into seven populations, based on geographic location (Table 1). The actual number of individuals in each group was Africa 117, India 53, Southern Europe 838, Northern Europe 650, Asia 343, Papua New Guinea 40, and the United States 265. The number of SNPs per population evaluated in the study ranged from three (India) to 36 (Southern Europe), with a total of 55 SNPs studied in MC1R in these analyses. AFs are shown in Table 2. Thirty-seven SNPs were nonsynonymous (NS) and 18 were synonymous (S). The greatest number of SNPs was present in individuals from Southern Europe (29 NS, 7 S) and Northern Europe (18 NS and 3 $S)$. The fewest number of SNPs were noted in the subjects from India (2 NS, 1 S), Papua New Guinea (2 NS, 2 S) and Africa (3 NS and 8 ).

In order to correct for the variable population sizes, which could contribute to the absolute number of SNPs identified, $\pi$ and $\theta$, measures of nucleotide diversity, were calculated. The overall nucleotide diversity for all SNPs in $M C 1 R$, as measured by $\pi$, was $10.1 \times 10^{-4}$ for all populations (2306 total subjects); it ranged from a low of $3.6 \times$ $10^{-4}$ in subjects from India to a high of $11.1 \times 10^{-4}$ from US subjects (Table 3 ). In subgroup analyses of the Northern and Southern European populations, $\pi$ was the highest in subjects from Britain $\left(18.1 \times 10^{-4}\right)$. $\theta$, the population mutation parameter, was quite variable across populations, ranging from $6 \times 10^{-4}$ in India to $47.3 \times 10^{-4}$ in Southern Europe. In Southern European subjects, $\theta$ was the highest, $43.6 \times 10^{-4}$, in Italy.

Table I: Description of populations and studies used for analyses of $M C I R$ allele frequencies

\begin{tabular}{|c|c|c|c|}
\hline Population Name & Description & \# Individuals & Reference \\
\hline Africa & $\begin{array}{l}\text { Healthy subjects from South Africa ( } 22 \text { Negroid and } 17 \text { San } \\
\text { people), } 25 \text { from South Africa, Nigeria, Zaire, Kenya and } \\
\text { Gambia, and } 53 \text { from The Ivory Coast and Gambia }\end{array}$ & 117 & John 2003, Rana 1999, Harding 2000 \\
\hline India & Healthy subjects from studies investigating MCIR variants. & 53 & Rana 1999, Harding 2000 \\
\hline Southern Europe & Healthy subjects from Spain (I88), Italy (495) and Greece (I55) & 838 & $\begin{array}{l}\text { Fernandez 2007, Harding2000, Fargnoli } \\
\text { 2003, Pastorino 2004, Landi 2005, } \\
\text { Fargnoli 2006, Stratigos 2006, }\end{array}$ \\
\hline Northern Europe & $\begin{array}{l}\text { Healthy subjects from The Netherlands ( } 385) \text {, Britain/Ireland } \\
\text { (93) and France (172) }\end{array}$ & 650 & $\begin{array}{l}\text { Bastiaens 200I, Kennedy 200 I, Flanagan } \\
2000 \text {, Harding 2000, Chaudru } 2005\end{array}$ \\
\hline Asia & $\begin{array}{l}\text { Healthy subjects from East and Southeast Asia. Rana et al } \\
\text { reported individuals from China (50), Japan (4), Cambodia (I), } \\
\text { Vietnam (I), Siberian Yakut (5) and Mongolia (4). The remaining } \\
\text { studies were of individuals from Japan. }\end{array}$ & 343 & $\begin{array}{l}\text { Rana 1999, Harding 2000, Motokawa } \\
\text { 2006, Nakayama } 2006\end{array}$ \\
\hline Papua New Guinea & Healthy subjects from studies investigating MCIR variants. & 40 & Harding 2000, Nakayama 2006 \\
\hline United States & $\begin{array}{l}\text { Healthy Caucasian subjects participating in a population based } \\
\text { study conducted in Philadelphia, PA and Caucasian spouse } \\
\text { controls from the US in a familial melanoma case/control study. }\end{array}$ & 265 & Kanetsky 2004, Goldstein 2005 \\
\hline
\end{tabular}


Table 2: Allele frequencies (\%) of MCIR single nucleotide polymorphisms in seven populations.

\begin{tabular}{|c|c|c|c|c|c|c|c|c|c|}
\hline protein & nucleotide & All subjects & Africa & Asia & India & NoEur & SoEur & US & PNG \\
\hline p.PI8A & $c .52 \mathrm{C}>\mathrm{G}$ & 0 & 0 & 0 & 0 & 0.08 & 0 & 0 & 0 \\
\hline p.C35Y & c. $104 \mathrm{G}>\mathrm{A}$ & 0 & 0 & 0 & 0 & 0 & 0.12 & 0 & 0 \\
\hline p.V38M & c. $112 \mathrm{G}>\mathrm{A}$ & 0 & 0 & 0 & 0 & 0 & 0.06 & 0 & 0 \\
\hline p.L44V & c. $130 \mathrm{C}>\mathrm{G}$ & 0 & 0 & 0 & 0 & 0 & 0.06 & 0 & 0 \\
\hline p.F45L & c. $133 \mathrm{~T}>\mathrm{C}$ & 0 & 0 & 0 & 0 & 0 & 0.24 & 0 & 0 \\
\hline p.S47I & c. $140 \mathrm{G}>\mathrm{T}$ & 0 & 0.43 & 0 & 0 & 0 & 0 & 0 & 0 \\
\hline P.L50L & c. $150 \mathrm{G}>\mathrm{A}$ & 0 & 1.28 & 0 & 0 & 0 & 0 & 0 & 0 \\
\hline p.V60L & c. $178 \mathrm{G}>\mathrm{T}$ & 0.10 & 0 & 0 & 0 & 10.69 & 15.75 & 13.21 & 0 \\
\hline p.R67Q & c. $200 \mathrm{G}>\mathrm{A}$ & 0 & 0 & 1.17 & 0 & 0 & 0.06 & 0 & 0 \\
\hline p.A8IP & $c .24 \mid \mathrm{G}>\mathrm{C}$ & 0 & 0 & 0 & 0 & 0.08 & 0 & 0 & 0 \\
\hline p.S83P & c. $247 \mathrm{~T}>\mathrm{C}$ & 0 & 0 & 0 & 0 & 0.15 & 0.12 & 0.19 & 0 \\
\hline p.S83L & c. $248 \mathrm{C}>\mathrm{T}$ & 0 & 0 & 0 & 0 & 0 & 0.06 & 0 & 0 \\
\hline p.D84E & c. 252 C>A & 0 & 0 & 0 & 0 & 1.00 & 0.12 & $1.5 \mid$ & 0 \\
\hline p.V92M & c. $274 \mathrm{G}>\mathrm{A}$ & 0.07 & 0 & $|3.4|$ & 0.94 & 8.00 & 3.70 & 9.06 & 3.75 \\
\hline р.T95M & c. $284 \mathrm{C}>\mathrm{T}$ & 0 & 0 & 0 & 0 & 0.08 & 0.12 & 0 & 0 \\
\hline p.L99| & c. $295 \mathrm{C}>\mathrm{A}$ & 0 & 0.43 & 0 & 0 & 0 & 0 & 0 & 0 \\
\hline p.AI03A & c.309 C>T & 0 & 0.43 & 0 & 0 & 0 & 0 & 0 & 0 \\
\hline P.LI06Q & c. $317 \mathrm{~T}>\mathrm{A}$ & 0 & 0 & 0 & 0 & 0 & 0.06 & 0 & 0 \\
\hline LI06L & c. $318 \mathrm{G}>\mathrm{A}$ & 0 & 1.71 & 0 & 0 & 0 & 0.12 & 0 & 0 \\
\hline p.AIIIV & c. $332 \mathrm{C}>\mathrm{T}$ & 0 & 0 & 0 & 0 & 0 & 0.18 & 0 & 0 \\
\hline p.II20T & c. $359 \mathrm{~T}>\mathrm{C}$ & 0 & 0 & 1.75 & 0 & 0 & 0.06 & 0 & 0 \\
\hline p.VI22M & c. $364 \mathrm{G}>\mathrm{A}$ & 0 & 0 & 0 & 0 & 0 & 0.24 & 0 & 0 \\
\hline p.VI22V & c. $366 \mathrm{G}>\mathrm{C}$ & 0 & 0 & 0 & 0 & 0 & 0.12 & 0 & 0 \\
\hline p.RI42H & c. $425 \mathrm{G}>\mathrm{A}$ & 0.01 & 0 & 0 & 0 & 0.62 & 1.31 & 0.75 & 0 \\
\hline P.RI5IC & c. 45 I C>T & 0.03 & 0 & 0 & 0 & 5.62 & 3.16 & 6.42 & 0 \\
\hline p.YI52X & c. 456 C>A & 0 & 0 & 0 & 0 & 0 & 0.06 & 0 & 0 \\
\hline p.II55T & c. $464 \mathrm{~T}>\mathrm{C}$ & 0 & 0 & 0 & 0 & 0.23 & 0.48 & $1.5 \mid$ & 0 \\
\hline p.RI60W & c. 478 C>T & 0.04 & 0 & 0 & 0 & 8.31 & 1.85 & 7.17 & 0 \\
\hline p.RI60Q & c. $479 \mathrm{G}>\mathrm{A}$ & 0 & 0 & 0 & 0 & 0 & 0.06 & 0 & 5 \\
\hline p.RI63Q & c. $488 \mathrm{G}>\mathrm{A}$ & 0.14 & 0 & 75.51 & 4.72 & 4.62 & 1.61 & 4.15 & 0 \\
\hline p.AI66A & c. $498 \mathrm{G}>\mathrm{A}$ & 0 & 0 & 0 & 0 & 0 & 0 & 0 & 11.25 \\
\hline p.II68I & c. $504 \mathrm{C}>\mathrm{T}$ & 0 & 0.43 & 0 & 0 & 0 & 0 & 0 & 0 \\
\hline P.AI7ID & c. $512 \mathrm{C}>\mathrm{A}$ & 0 & 0 & 0 & 0 & 0 & 0.06 & 0 & 0 \\
\hline p.VI74I & c. $520 \mathrm{G}>\mathrm{A}$ & 0 & 0 & 0 & 0 & 0.08 & 0 & 0 & 0 \\
\hline p.YI82Y & c.546 C>T & 0 & 0 & 0 & 0 & 0 & 0 & 0.19 & 0 \\
\hline p.FI96L & c.586 T>C & 0 & 2.14 & 0.15 & 0 & 0.08 & 0 & 0 & 0 \\
\hline p.R2I3W & c.637 C>T & 0 & 0 & 0 & 0 & 0 & 0.06 & 0 & 0 \\
\hline p.G220G & c. $660 \mathrm{C}>\mathrm{T}$ & 0 & 0 & 0 & 0 & 0 & 0.06 & 0 & 0 \\
\hline p.Q228Q & c. $684 \mathrm{G}>\mathrm{A}$ & 0 & 0 & 0 & 0 & 0 & 0.12 & 0 & 0 \\
\hline p.P230L & c.689 C>T & 0 & 0 & 0 & 0 & 0.31 & 0 & 0 & 0 \\
\hline p.P230P & c. $690 \mathrm{G}>\mathrm{A}$ & 0 & 0 & 0 & 0 & 0.08 & 0 & 0 & 0 \\
\hline p.Q233Q & c.699 G>A & 0 & 0 & 0 & 0 & 0 & 0.36 & 0.19 & 0 \\
\hline p.A240A & c. $720 \mathrm{~T}>\mathrm{C}$ & 0 & 0 & 0 & 0 & 0 & 0 & 0.19 & 0 \\
\hline p.T242T & c.726 C>T & 0 & 0 & 0 & 0 & 0 & 0.12 & 0 & 0 \\
\hline p.G248V & c.743 G>T & 0 & 0 & 0 & 0 & 0 & 0.06 & 0 & 0 \\
\hline p.H260P & c. $779 \mathrm{~A}>\mathrm{C}$ & 0 & 0 & 0 & 0 & 0.23 & 0 & 0 & 0 \\
\hline p.1264l & c.792 C>T & 0 & 0 & 0 & 0 & 0.15 & 0 & 0 & 0 \\
\hline p.V265V & c.795 C>G & 0 & 1.28 & 0 & 0 & 0 & 0 & 0 & 0 \\
\hline p.C273C & $\mathrm{c} .819 \mathrm{C}>\mathrm{T}$ & 0 & 0.43 & 0 & 0 & 0 & 0 & 0 & 0 \\
\hline p.K278E & c. $832 \mathrm{~A}>\mathrm{G}$ & 0 & 0 & 0 & 0 & 0.23 & 0.24 & 0 & 0 \\
\hline p.N279K & c. $837 \mathrm{C}>\mathrm{A}$ & 0 & 0 & 0 & 0 & 0 & 0.06 & 0 & 0 \\
\hline p.D294H & $\mathrm{c} .880 \mathrm{G}>\mathrm{C}$ & 0.01 & 0 & 0 & 0 & 1 & 1.43 & 2.45 & 0 \\
\hline p.F300F & c. $900 \mathrm{C}>\mathrm{T}$ & 0 & 2.99 & 0 & 0 & 0 & 0 & 0 & 0 \\
\hline p.T308M & c. $923 \mathrm{C}>\mathrm{T}$ & 0 & 0 & 0 & 0 & 0 & 0.06 & 0 & 0 \\
\hline p.T3।4T & c. $942 \mathrm{~A}>\mathrm{G}$ & 0.09 & 44.44 & 13.27 & 13.21 & 7.69 & 2.33 & 10.75 & 18.75 \\
\hline
\end{tabular}

Abbreviations: SoEur, Southern Europe, NoEur, Northern Europe, PNG, Papua New Guinea, US, United States. Allele frequency \% were rounded to two decimal places, therefore, rare alleles may be reported as zero due to rounding. 
Table 3: MCIR nucleotide diversity, Tajima's $D$, and Fu's $F_{S}$ statistic for seven populations Statistically significant values are bolded.

\begin{tabular}{|c|c|c|c|c|c|c|c|c|c|c|}
\hline & \multicolumn{4}{|c|}{$\pi \times 10^{-4}$} & \multicolumn{2}{|c|}{$\theta \times 10^{-4}$} & \multirow[b]{2}{*}{$\begin{array}{l}\text { Tajima's D } \\
\text { statistic }\end{array}$} & \multirow[b]{2}{*}{$\begin{array}{c}\text { Tajima's D p- } \\
\text { value }\end{array}$} & \multirow[b]{2}{*}{ Fu's $F_{S}$} & \multirow[b]{2}{*}{ Fu's $\mathrm{F}_{\mathrm{S}} \mathrm{P}$-value } \\
\hline & \# SNPs & \# NS SNPs & All SNPs & NS only & All SNPs & NS only & & & & \\
\hline Africa & 11 & 3 & 7.6 & 0.6 & 19.2 & 5.2 & -1.41 & 0.048 & -0.24 & 0.436 \\
\hline India & 3 & 2 & 3.6 & 1.2 & 6.0 & 4.0 & -0.72 & 0.27 & -1.27 & 0.202 \\
\hline SoEur & 36 & 29 & 6.7 & 6.0 & 47.3 & 38.1 & -2.13 & $<0.001$ & -27.92 & $<0.001$ \\
\hline Greece & 12 & 10 & 5.3 & 4.2 & 20.0 & 16.7 & $-|.7|$ & 0.008 & -3.81 & 0.071 \\
\hline Italy & 31 & 26 & 7.1 & 6.8 & 43.6 & 36.6 & -2.10 & $<0.001$ & -6.46 & 0.055 \\
\hline Spain & 17 & 15 & 6.7 & 5.4 & 27.5 & 24.2 & -1.85 & 0.003 & -8.44 & 0.009 \\
\hline NoEur & 21 & 18 & 9.6 & 8.1 & 28.5 & 24.4 & -1.53 & 0.026 & -23.66 & $<0.001$ \\
\hline Britain & 10 & 10 & 18.1 & 10.9 & 10.9 & 18.1 & -0.94 & 0.181 & -2.07 & 0.207 \\
\hline France & 12 & 10 & 9.4 & 7.4 & 19.7 & 16.4 & -1.20 & 0.099 & -2.92 & 0.131 \\
\hline Netherlands & 16 & 14 & 9.3 & 7.6 & 23.3 & 20.4 & -1.36 & 0.047 & -4.74 & 0.095 \\
\hline US & 14 & 10 & 11.1 & 9.0 & 21.5 & 15.4 & -1.10 & 0.126 & -2.41 & 0.212 \\
\hline Asia & 6 & 5 & 9.4 & 7.0 & 8.9 & 7.4 & 1.05 & 0.855 & 2.15 & 0.839 \\
\hline PNG & 4 & 2 & 7.2 & 1.8 & 8.5 & 4.2 & -0.33 & 0.433 & -0.78 & 0.301 \\
\hline
\end{tabular}

Abbreviations: SNPs, single nucleotide polymorphisms; NS, nonsynonymous; SoEur, Southern Europe; NoEur, Northern Europe; PNG, Papua New Guinea; US, United States

Nucleotide diversity was also calculated for NS SNPs only to further understand the contribution of these SNPs to $M C 1 R$ genetic variation (Table 3 ). $\pi$ in NS SNPs ranged from a low of $0.6 \times 10^{-4}$ in subjects from Africa to a high of $9.0 \times 10^{-4}$ in the US. Within the European populations, $\pi$ for NS SNPs was the greatest in Britain $\left(10.9 \times 10^{-4}\right)$. As was seen for all SNPs, $\theta$ for NS SNPs was the highest in Italy $\left(36.6 \times 10^{-4}\right)$.

In addition to a high degree of inter-population variability, MC1R has a higher degree of nucleotide diversity in comparison to other groups of genes (Table 4). Studies of genetic variation in various gene groups, e.g., genes important in telomere biology [33], antigen processing and presenting genes [34], pharmaceutical response [35], and environmental response genes [36], showed $\pi$ values ranging from $3.0 \times 10^{-4}$ to $6.7 \times 10^{-4}$, while all seven populations studied for MC1R had a combined $\pi$ value of
$10.1 \times 10^{-4}$. $\theta$ showed similarly higher values in MC1R $\left(64.2 \times 10^{-4}\right)$ than in other sets of genes $\left(\right.$ all $\left.<8.4 \times 10^{-4}\right)$.

\section{Population Differentiation}

The $\mathrm{F}_{\mathrm{ST}}$ statistic, a pairwise measure of population differentiation, has been used extensively to compare the degrees of heterozygosity across populations $[2,37]$. Therefore, $M C 1 R \mathrm{~F}_{\mathrm{ST}}$ was calculated for each of the described populations (Table 5). Overall, a very high degree of differentiation was noted between Asia and each of the other groups; $\mathrm{F}_{\mathrm{ST}}$ ranged from 0.459 between Asia and Africa to 0.356 between Asia and the United States.

The degree of differentiation between subjects from Africa and the six other groups ranged from 0.101 (Papua New Guinea) to 0.232 (Southern Europe). Papua New Guinea had relatively modest degrees of population differentiation when compared to all populations except Asia, where

Table 4: Comparison of MCIR nucleotide diversity and Tajima's $D$ statistic to other sets of genes. These data include subjects from different ethnic groups calculated as a whole. The number of genes evaluated is shown in parentheses.

\begin{tabular}{lccccc}
\hline & $\pi \times 10^{-4}$ & $\theta \times 10^{-4}$ & \# NS/kbp & \#S/kbp & Tajima's D statistic \\
\hline MCIR & 10.1 & 64.2 & 38.9 & 18.9 & -2.08 \\
Telomere biology genes $^{\mathrm{a}}(\mathrm{n}=7)$ & 3.0 & 5.5 & 0.59 & 1.01 & -1.365 \\
Nuclear hormone receptor genes $^{\mathrm{b}}(\mathrm{n}=40)$ & 4.1 & 7.5 & 1.55 & 1.97 & ND \\
Antigen processing and presenting genes $^{\mathrm{b}}(\mathrm{n}=72)$ & 4.7 & 8.3 & 2.29 & 1.99 & ND \\
Reference genes $^{\mathrm{b}}(\mathrm{n}=4950)$ & 4.8 & 7.9 & 1.88 & 1.86 & ND \\
Pharmaceutical Response genes $^{\mathrm{c}}(\mathrm{n}=1598)$ & 5.6 & ND & ND & ND & negative \\
Environmental response genes $^{\mathrm{d}}(\mathrm{n}=213)$ & 6.7 & ND & ND & ND & ND \\
\hline
\end{tabular}

aSavage et al. [2005].

bPungliya et al. [2004].

cSchneider et al. [2003].

dLivingston et al. [2004].

Abbreviations: NS, nonsynonymous, S, synonymous, ND, not determined in the reference manuscript. 
Table 5: $\mathrm{F}_{\mathrm{ST}}$ statistic for $M C I R$ in seven populations.

\begin{tabular}{lcccccc}
\hline & India & SoEur & NoEur & Asia & PNG & US \\
\hline Africa & 0.157 & 0.232 & 0.168 & 0.459 & 0.101 & 0.145 \\
India & & 0.073 & 0.042 & 0.455 & 0.029 & 0.044 \\
SoEur & & & 0.016 & 0.437 & 0.089 & 0.017 \\
NoEur & & & & 0.369 & 0.057 & 0.001 \\
Asia & & & & & 0.430 & 0.356 \\
PNG & & & & & & 0.053 \\
\hline
\end{tabular}

Abbreviations: SoEur, Southern Europe, NoEur, Northern Europe, PNG, Papua New Guinea, US, United States.

it was very large. The least amount of population differentiation was found in comparisons between the United States, Northern Europe, and Southern Europe.

We also performed analyses on the subpopulations that comprised the Northern Europe (Britain, the Netherlands, and France) and the Southern Europe (Greece, Italy, and Spain) groups. $\mathrm{F}_{\mathrm{ST}}$ values for all of these comparisons were between 0 and 0.03 , suggestive of little differentiation (data not shown).

\section{Selection}

Several studies have identified signals of positive selection in pigmentation genes in subjects from East Asia, and Europe but not from those in Africa[2,38,39]. Whether or not positive selection is present at the MC1R locus, is an area of active investigation. Previous work suggested that the high degree of variation in MC1R is not due to selection but rather to a relaxation of functional constraint outside of Africa [25]. In order to further test this hypothesis we first determined Tajima's D statistic, a measure of the relationship between the number of segregating sites (SNPs) and nucleotide diversity (Table 3). It was not statistically significant $(\mathrm{p}>0.05)$ in the populations from India, Asia, Papua New Guinea, and the United States, in which Tajima's D values were $-0.72,1.05,-0.33$, and 1.10 , respectively. The African population studied had Tajima's D value of -1.41 and a p-value of 0.048 . Statistically significant and negative Tajima's $\mathrm{D}$ values were present in the Southern European population $(-2.13, \mathrm{p}=$ $<0.001)$. Subgroup analyses of this population showed the same trend, with negative Tajima's D values and p-values $<0.05$ in Greece, Italy, and Spain. The combined Northern European group had a Tajima's D value of -1.53 $(p=0.026)$. However, only the population from the Netherlands had a statistically significant Tajima's $D$ value in this group $(-1.36, \mathrm{p}=0.047)$.

The $\mathrm{F}_{\mathrm{S}}$ test of neutrality developed by Fu (1997) and based on $\theta$ is a powerful method to further evaluate the polymorphic patterns under population growth and genetic hitchhiking. These values are shown in Table 3. Fu's $F_{S}$ was statistically significant in the grouped Southern European population $(-27.92, \mathrm{p}=<0.001)$ but only in the subpopulation from Spain $(-8.44, \mathrm{p}=0.009)$. The Northern European population group also had a statistically significant $\mathrm{F}_{\mathrm{S}}$ value $(-23.66, \mathrm{p}=<0.001)$. The $\mathrm{F}_{\mathrm{S}}$ values were not statistically significant in the other populations. Fu and Li's $D$ values were comparable in scope to Tajima's D in this study but p-values were not obtainable due to software limitations (data not shown).

\section{Discussion}

$M C 1 R$ is a small, highly variant gene. This study evaluated the nucleotide diversity, population-specific differentiation, and tested for positive selection of $M C 1 R$ based on a compilation of previously published data. We used allele frequencies from studies that reported sequencing the entire gene and used the 951 coding bp of MC1R as the reference sequence. The genotype data used for these analyses was derived from the sample size and reported AFs, as a result, we were unable to assess the haplotype structure of MC1R. Also, we could not assess the flanking sequences of $M C 1 R$ because the exact regions sequenced were not reported in the published data.

We observed that nucleotide diversity, as measured by $\pi$ and $\theta$, was greater in $M C 1 R$ than in other groups of genes. It should be noted that these differences may be somewhat skewed because our study evaluated only one, small gene, MC1R, while the other studies evaluated between 7 and 4950 different genes [33-36]. Several other studies have noted the highly polymorphic nature of $M C 1 R$ (compiled by Gerstenblith et al. [29]). Overall, the largest degree of nucleotide diversity was seen between Asia and all other populations, most likely due to the presence of the R163Q (c.488 G>A) SNP, which was present in 75\% of Asians studied, versus less than 5\% of any of the other six populations. It has been suggested that this allele may be present due to a bottleneck in Asian demographic history [25]. This allele has been shown to have reduced cell surface expression with corresponding impairment in cAMP coupling and effects in pigmentation [13].

The $\mathrm{F}_{\mathrm{ST}}$ statistic was calculated to further assess the degree of population-specific differentiation in MC1R. Numerous population-specific SNPs and an overall high degree of population differentiation, as measured by $\mathrm{F}_{\mathrm{ST}}$ between populations, are present in $M C 1 R$, particularly in Asians. Minimal differentiation was noted between Southern Europe, Northern Europe, and the United States. These individuals were identified in previous studies as Caucasian (i.e. of European descent), and likely share some degree of common ancestry. Although frequency of specific variants differ across populations of European descent (e.g. the allele frequency of the $\mathrm{T}$ allele of c. $451 \mathrm{C}>\mathrm{T}$, p.R151C, was $1.9 \%$ in Greece but $10.2 \%$ in Britain/Ireland[29]), the sub-group analysis of the North- 
ern and Southern European groups showed little evidence of population differentiation. This is consistent with other studies showing little among-population differentiation $[25,27,30]$. The African population in this study had moderate to large degrees of differentiation in comparison to other populations. This is consistent with prior $M C 1 R$ SNP data showing fewer variants in individuals from Africa when compared to non-African populations[29].

Tajima's D statistic tests whether or not a gene or genomic region is evolving randomly (neutral evolution) or if the region is under selection (non-neutral evolution). It is based on the spectrum of AFs at different sites, as well as on population size. Tajima's D statistic was used to test $M C 1 R$ for the presence of selection. These data, which are based on the very large sample size described herein, suggest that positive selection may be present in the Southern European population as a whole, as well as in its three subgroups, Greece, Italy, and Spain, based on the presence of negative Tajima $D$ values and statistically significant $p$ values. The data also suggest the presence of some degree of positive selection in the Northern European population; but only the subgroup from the Netherlands had statistically significant p-values. It should be noted that Tajima's D statistic assumes that all nucleotides are equally mutable, subject to the same population dynamics, and can be misleading if a significant population bottleneck occurred. We also used Fu's $\mathrm{F}_{\mathrm{S}}$ test to address the presence of positive selection versus neutral evolution of $M C 1 R$. This was statistically significant only in the Southern and Northern European groups and the subpopulation from Spain and further suggests the presence of positive selection in the European populations. However, our data are also limited because we were only able to study the $951 \mathrm{bp}$ of coding sequence in $M C 1 R$ and were not able to assess the larger genomic region.

Several studies have evaluated genetic adaptation of the $M C 1 R$ gene for evidence of positive selection with conflicting results. Some studies suggested that purifying selection is present in Africa and that relaxation of functional constraint in non-African populations, instead of positive selection, is present $[25,27,40]$. On the other hand, most recent studies have found evidence of positive selection at other pigmentation genes. For example, Myles et al [2] found evidence for positive selection in the DCT gene among individuals of Chinese ancestry. In their study, MC1R interpretations were limited because of the different SNPs genotyped between the Perlegen and HapMap data sets studied. In a study of 118 putative skin pigmentation genes, data were consistent with positive selection in subjects from Europe (OCA2, TYRP1, and KITLG) and in Asians (DCT, EGFR, and DRD2)[38]. Unfortunately, MC1R could not be evaluated in that study due to ascertainment criteria. It was also suggested that at least weak, recent positive selection may be present in $M C 1 R$, based on the AF variability between CEPH Utah and East Asian HapMap samples[3]. Our data suggest that $M C 1 R$ may be under positive selection in some populations, although additional studies are needed to further evaluate this finding.

\section{Conclusion}

This study further quantifies the degree of MC1R genetic variation, illustrates the complexity of this variation across numerous populations, and suggests that positive selection plays a role in European populations. Understanding of population-specific genetic variation in MC1R and the role it plays not just in skin pigmentation, but sun sensitivity and melanoma risk, has the potential to impact clinical care and public health.

\section{Methods}

AF data of MC1R SNPs from populations around the world were compiled as described [29], from twenty-two skin cancer case-control and population studies that fully sequenced $M C 1 R$ in distinct populations. From the studies included in Gerstenblith et al [29], we restricted our analyses to those that included data from healthy, control individuals $\quad[7,8,16,18,19,21,22,25,27,40-47]$. We excluded studies that noted only the presence of a SNP but not actual AFs $[4,48,49]$, that measured AFs on family members $[4,9,18]$, that were restricted to the extremes of hair and skin color phenotypes [6], or to ethnically diverse groups in which it was not possible to determine the AFs for each ethnic group [17]. In addition, the study of $M C 1 R$ variants in individuals from Spain was also included [22]. Populations from Europe and the United States were identified as Caucasian individuals in these studies. European populations were combined based on geographic locations. Northern Europe consisted on subjects from Britain, France, and the Netherlands. Southern Europe consisted of subjects from Greece, Italy, and Spain. The populations and studies from which they were derived are shown in Table 1.

Genotype data files were created from AFs for each population (Table 2) and were then analyzed in DNAsp version 4.0 [50]. The 951 base pairs (bp) of coding MC1R sequence (NM_002386) was used as the template. Since data files were created from AFs, we were unable to assess the haplotype structure of MC1R. Analyses were performed that were not dependent on haplotype structure. Nucleotide diversity $(\pi)$, the average number of nucleotide substitutions per site between two sequences, was calculated with the Jukes and Cantor correction [51]. Theta $(\theta$ ), the population mutation parameter (two times the mutation rate per site per generation times the number of heritable units in the population), was calcu- 
lated on a base pair basis from the total number of segregating sites (SNPs) under the no recombination model [52]. Genetic differentiation among populations was measured by $\mathrm{F}_{\mathrm{ST}}[53]$. Arlequin (v3.11) was used to determine Tajima's D statistic and Fu's $F_{S}$ test [54] under a neutral model with 1000 simulations [55,56]. Other genes and corresponding estimates of population differentiation were selected for comparison with $M C 1 R$ values [33$36]$.

\section{Authors' contributions}

SAS participated in the study design, performed all the population genetics analyses, data interpretation, and wrote the manuscript. MRG reviewed all manuscripts related to $M C 1 R$, analyzed the MC1R frequency in each population, summarized all data for the population genetics analyses, and participated in data analysis and interpretation. AMG participated in the study design and oversaw statistical analyses and data interpretation; LM participated in data analysis and interpretation. MCF and KP participated in the study design and data interpretation. MTL was responsible for the conception and design of the study, and oversaw data analysis and interpretation. All authors contributed to the manuscript's writing and review.

\section{Acknowledgements}

This research was supported by the Intramural Research Program of the National Institutes of Health, National Cancer Institute, Division of Cancer Epidemiology and Genetics. We thank Dr. Meredith Yeager, and Brian Staats, NCl, SAIC-Frederick for valuable advice. We also thank the reviewers for helpful comments.

\section{References}

I. Izagirre N, Garcia I, Junquera C, de la RC, Alonso S: A scan for signatures of positive selection in candidate loci for skin pigmentation in humans. Mol Biol Evol 2006, 23: 1697-I706.

2. Myles S, Somel M, Tang K, Kelso J, Stoneking M: Identifying genes underlying skin pigmentation differences among human populations. Hum Genet 2007, I 20:613-62I.

3. Sulem P, Gudbjartsson DF, Stacey SN, Helgason A, Rafnar T, Magnusson KP, Manolescu A, Karason A, Palsson A, Thorleifsson G, Jakobsdottir M, Steinberg S, Palsson S, Jonasson F, Sigurgeirsson B, Thorisdottir K, Ragnarsson R, Benediktsdottir KR, Aben KK, Kiemeney LA, Olafsson JH, Gulcher J, Kong A, Thorsteinsdottir U, Stefansson K: Genetic determinants of hair, eye and skin pigmentation in Europeans. Nat Genet 2007, 39: |443-| 452.

4. Box NF, Wyeth JR, O'Gorman LE, Martin NG, Sturm RA: Characterization of melanocyte stimulating hormone receptor variant alleles in twins with red hair. Hum Mol Genet 1997, 6:1891-1897.

5. Smith R, Healy E, Siddiqui S, Flanagan N, Steijlen PM, Rosdahl I, Jacques JP, Rogers S, Turner R, Jackson IJ, Birch-Machin MA, Rees JL: Melanocortin I receptor variants in an Irish population. J Invest Dermatol 1998, I I I:I I9-122.

6. Valverde P, Healy E, Jackson I, Rees JL, Thody AJ: Variants of the melanocyte-stimulating hormone receptor gene are associated with red hair and fair skin in humans. Nat Genet 1995, I I:328-330.

7. Bastiaens M, ter Huurne J, Gruis N, Bergman W, Westendorp R, Vermeer BJ, Bouwes Bavinck JN: The melanocortin- I-receptor gene is the major freckle gene. Hum Mol Genet 200I, I 0:I701-I708.

8. Flanagan N, Healy E, Ray A, Philips S, Todd C, Jackson IJ, Birch-Machin MA, Rees JL: Pleiotropic effects of the melanocortin I recep- tor (MCIR) gene on human pigmentation. Hum Mol Genet 2000, 9:2531-2537.

9. Duffy DL, Box NF, Chen W, Palmer JS, Montgomery GW, James MR, Hayward NK, Martin NG, Sturm RA: Interactive effects of MCIR and OCA2 on melanoma risk phenotypes. Hum Mol Genet 2004, 1 3:447-46I.

10. Schioth HB, Phillips SR, Rudzish R, Birch-Machin MA, Wikberg JE, Rees JL: Loss of function mutations of the human melanocortin I receptor are common and are associated with red hair. Biochem Biophys Res Commun 1999, 260:488-49I.

II. Garcia-Borron JC, Sanchez-Laorden BL, Jimenez-Cervantes C: Melanocortin-I receptor structure and functional regulation. Pigment Cell Res 2005, I 8:393-4I0.

12. Wong TH, Rees JL: The relation between melanocortin I receptor (MCIR) variation and the generation of phenotypic diversity in the cutaneous response to ultraviolet radiation. Peptides 2005, 26:1965-1971.

13. Beaumont KA, Shekar SL, Newton RA, James MR, Stow JL, Duffy DL, Sturm RA: Receptor function, dominant negative activity and phenotype correlations for MCIR variant alleles. Hum Mol Genet 2007, I 6( I 8):2249-60.

14. Valverde P, Healy E, Sikkink S, Haldane F, Thody AJ, Carothers A, Jackson IJ, Rees JL: The Asp84Glu variant of the melanocortin I receptor (MCIR) is associated with melanoma. Hum Mol Genet 1996, 5:1663-1666.

15. Palmer JS, Duffy DL, Box NF, Aitken JF, O'Gorman LE, Green AC, Hayward NK, Martin NG, Sturm RA: Melanocortin-I receptor polymorphisms and risk of melanoma: is the association explained solely by pigmentation phenotype? Am J Hum Genet 2000, 66:176-186.

16. Kennedy C, ter Huurne J, Berkhout M, Gruis N, Bastiaens M, Bergman W, Willemze R, Bavinck JN: Melanocortin I receptor (MCIR) gene variants are associated with an increased risk for cutaneous melanoma which is largely independent of skin type and hair color. J Invest Dermatol 2001, I I 7:294-300.

17. Matichard E, Verpillat P, Meziani R, Gerard B, Descamps V, Legroux E, Burnouf M, Bertrand G, Bouscarat F, Archimbaud A, Picard C, Ollivaud L, Basset-Seguin N, Kerob D, Lanternier G, Lebbe C, Crickx B, Grandchamp B, Soufir N: Melanocortin I receptor (MCIR) gene variants may increase the risk of melanoma in France independently of clinical risk factors and UV exposure. J Med Genet 2004, 4I:el3.

18. Landi MT, Kanetsky PA, Tsang S, Gold B, Munroe D, Rebbeck T, Swoyer J, Ter Minassian M, Hedayati M, Grossman L, Goldstein AM, Calista D, Pfeiffer RM: MCIR, ASIP, and DNA repair in sporadic and familial melanoma in a Mediterranean population. J Natl Cancer Inst 2005, 97:998-1007.

19. Fargnoli MC, Altobelli E, Keller G, Chimenti S, Hofler H, Peris K: Contribution of melanocortin-I receptor gene variants to sporadic cutaneous melanoma risk in a population in central Italy: a case-control study. Melanoma Res 2006, I 6: I75-182.

20. Kanetsky PA, Rebbeck TR, Hummer AJ, Panossian S, Armstrong BK, Kricker A, Marrett LD, Millikan RC, Gruber SB, Culver HA, Zanetti R, Gallagher RP, Dwyer T, Busam K, From L, Mujumdar U, Wilcox H, Begg CB, Berwick M: Population-based study of natural variation in the melanocortin-I receptor gene and melanoma. Cancer Res 2006, 66:9330-9337.

21. Stratigos AJ, Dimisianos G, Nikolaou V, Poulou M, Sypsa V, Stefanaki I, Papadopoulos O, Polydorou D, Plaka M, Christofidou E, Gogas H, Tsoutsos D, Kastana O, Antoniou C, Hatzakis A, Kanavakis E, Katsambas AD: Melanocortin receptor-I gene polymorphisms and the risk of cutaneous melanoma in a low-risk southern European population. J Invest Dermatol 2006, I 26: I842-I849.

22. Fernandez L, Milne R, Bravo J, Lopez J, Aviles J, Longo M, Benitez J, Lazaro P, Ribas G: MCIR: Three novel variants identified in a malignant melanoma association study in the Spanish population. Carcinogenesis 2007.

23. Landi MT, Bauer J, Pfeiffer RM, Elder DE, Hulley B, Minghetti P, Calista $D$, Kanetsky PA, Pinkel D, Bastian BC: MCIR germline variants confer risk for BRAF-mutant melanoma. Science 2006, 3 1 3:521-522.

24. Jablonski NG, Chaplin G: The evolution of human skin coloration. J Hum Evol 2000, 39:57-106.

25. Harding RM, Healy E, Ray AJ, Ellis NS, Flanagan N, Todd C, Dixon C, Sajantila A, Jackson IJ, Birch-Machin MA, Rees JL: Evidence for var- 
iable selective pressures at MCIR. Am J Hum Genet 2000, 66: $|35|-|36|$.

26. Rees JL: Genetics of hair and skin color. Annu Rev Genet 2003, 37:67-90.

27. Rana BK, Hewett-Emmett D, Jin L, Chang BH, Sambuughin N, Lin M, Watkins S, Bamshad M, Jorde LB, Ramsay M, Jenkins T, Li WH: High polymorphism at the human melanocortin I receptor locus. Genetics 1999, 15 I: 1547-1557.

28. Aoki K: Sexual selection as a cause of human skin colour variation: Darwin's hypothesis revisited. Ann Hum Biol 2002, 29:589-608.

29. Gerstenblith MR, Goldstein AM, Fargnoli MC, Peris K, Landi MT: Comprehensive evaluation of allele frequency differences of MCIR variants across populations. Hum Mutat 2007, 28:495-505.

30. Makova K, Norton H: Worldwide polymorphism at the MCIR locus and normal pigmentation variation in humans. Peptides 2005, 26: 1901-1908.

31. Akey JM, Eberle MA, Rieder MJ, Carlson CS, Shriver MD, Nickerson DA, Kruglyak L: Population History and Natural Selection Shape Patterns of Genetic Variation in 132 Genes. PLoS Biol 2004, 2:E286.

32. Kidd KK, Pakstis AJ, Speed WC, Kidd JR: Understanding human DNA sequence variation. J Hered 2004, 95:406-420.

33. Savage SA, Stewart BJ, Eckert A, Kiley M, Liao JS, Chanock SJ: Genetic variation, nucleotide diversity, and linkage disequilibrium in seven telomere stability genes suggest that these genes may be under constraint. Hum Mutat 2005, 26:343-350.

34. Pungliya MS, Salisbury BA, Nandabalan K, Stephens JC: Genetic variability and evolution of two pharmacologically important classes of genes. Pharmacogenomics 2004, 5: I I5-127.

35. Schneider JA, Pungliya MS, Choi JY, Jiang R, Sun XJ, Salisbury BA, Stephens JC: DNA variability of human genes. Mech Ageing Dev 2003, I 24:17-25.

36. Livingston RJ, von Niederhausern A, Jegga AG, Crawford DC, Carlson CS, Rieder MJ, Gowrisankar S, Aronow BJ, Weiss RB, Nickerson DA: Pattern of sequence variation across 213 environmental response genes. Genome Res 2004, 14:182I-I83I.

37. Hinds DA, Stuve LL, Nilsen GB, Halperin E, Eskin E, Ballinger DG, Frazer KA, Cox DR: Whole-genome patterns of common DNA variation in three human populations. Science 2005, 307:1072-1079.

38. Lao O, de Gruijter JM, van Duijn K, Navarro A, Kayser M: Signatures of positive selection in genes associated with human skin pigmentation as revealed from analyses of single nucleotide polymorphisms. Ann Hum Genet 2007, 71:354-369.

39. McEvoy B, Beleza S, Shriver MD: The genetic architecture of normal variation in human pigmentation: an evolutionary perspective and model. Hum Mol Genet 2006, 15 (2):RI76-RI8I.

40. John PR, Makova K, Li WH, Jenkins T, Ramsay M: DNA polymorphism and selection at the melanocortin-I receptor gene in normally pigmented southern African individuals. Ann NY Acad Sci 2003, 994:299-306.

41. Chaudru V, Laud K, Avril MF, Miniere A, Chompret A, Bressac-de Paillerets B, Demenais F: Melanocortin-I receptor (MCIR) gene variants and dysplastic nevi modify penetrance of CDKN2A mutations in French melanoma-prone pedigrees. Cancer Epidemiol Biomarkers Prev 2005, 14:2384-2390.

42. Motokawa T, Kato T, Hongo M, Ito M, Takimoto H, Katagiri T, Hashimoto Y: Characteristic MCIR polymorphism in the Japanese population. J Dermatol Sci 2006, 41:143-| 45.

43. Nakayama K, Soemantri A, Jin F, Dashnyam B, Ohtsuka R, Duanchang $P$, Isa MN, Settheetham-Ishida W, Harihara S, Ishida T: Identification of novel functional variants of the melanocortin I receptor gene originated from Asians. Hum Genet 2006, I I 9:322-330.

44. Kanetsky PA, Ge F, Najarian D, Swoyer J, Panossian S, Schuchter L, Holmes R, Guerry D, Rebbeck TR: Assessment of polymorphic variants in the melanocortin-I receptor gene with cutaneous pigmentation using an evolutionary approach. Cancer Epidemiol Biomarkers Prev 2004, 1 3:808-8I 9.

45. Goldstein AM, Landi MT, Tsang S, Fraser MC, Munroe DJ, Tucker MA: Association of MCIR variants and risk of melanoma in melanoma-prone families with CDKN2A mutations. Cancer Epidemiol Biomarkers Prev 2005, 14:2208-22I2.
46. Fargnoli MC, Chimenti S, Keller G, Hofler H, Peris K: Identification of four novel melanocortin I receptor (MCIR) gene variants in a Mediterranean population. Hum Mutat 2003, $21: 655$.

47. Pastorino L, Cusano R, Bruno W, Lantieri F, Origone P, Barile M, Gliori S, Shepherd GA, Sturm RA, Bianchi-Scarra G: Novel MCIR variants in Ligurian melanoma patients and controls. Hum Mutat 2004, 24: 103.

48. Peng S, Lu XM, Luo HR, Xiang-Yu JG, Zhang YP: Melanocortin-I receptor gene variants in four Chinese ethnic populations. Cell Res 200I, I I:8I-84

49. Na GY, Lee KH, Kim MK, Lee SJ, Kim DW, Kim JC: Polymorphisms in the melanocortin-I receptor (MCIR) and agouti signaling protein (ASIP) genes in Korean vitiligo patients. Pigment Cell Res 2003, 16:383-387.

50. Rozas J, Sanchez-DelBarrio JC, Messeguer X, Rozas R: DnaSP, DNA polymorphism analyses by the coalescent and other methods. Bioinformatics 2003, 19:2496-2497.

5I. Jukes TH, Cantor CR: Evolution of protein molecules. In Mammalian Protein Metabolism Edited by: Munro EN. New York, Academic Press; 1969:21-132.

52. Nei M, Gojobori T: Simple methods for estimating the numbers of synonymous and nonsynonymous nucleotide substitutions. Mol Biol Evol 1986, 3:418-426.

53. Hudson RR, Slatkin M, Maddison WP: Estimation of levels of gene flow from DNA sequence data. Genetics 1992, I 32:583-589.

54. Fu YX: Statistical tests of neutrality of mutations against population growth, hitchhiking and background selection. Genetics 1997, 147:915-925.

55. Tajima F: Statistical method for testing the neutral mutation hypothesis by DNA polymorphism. Genetics 1989, I 23:585-595.

56. Excoffier L, Laval G, Schneider S: An integrated software package for population genetics data analysis. Evolutionary Bioinformatics Online 2005, I:47-50.

Publish with Bio Med Central and every scientist can read your work free of charge

"BioMed Central will be the most significant development for disseminating the results of biomedical research in our lifetime. "

Sir Paul Nurse, Cancer Research UK

Your research papers will be:

- available free of charge to the entire biomedical community

- peer reviewed and published immediately upon acceptance

- cited in PubMed and archived on PubMed Central

- yours - you keep the copyright

Submit your manuscript here:

http://www.biomedcentral.com/info/publishing_adv.asp
BioMedcentral 